\title{
Glacier-Climate Models as Palaeoclimatic Information Sources: Examples from the Alpine Younger Dryas Period
}

\author{
Hanns Kerschner \\ Institut für Geographie, Universität Innsbruck, Innrain 52, A-6020 Innsbruck, Austria \\ phone+43-512-507 5409, fax +43-512-507 2895, e-mail Hanns.Kerschner@uibk.ac.at
}

Keywords: Alps, Glaciers, Glacier-climate models, Precipitation, Younger Dryas.

\section{Introduction}

The regional distribution of precipitation in a mountain range like the European Alps is a good indicator for continental-scale atmospheric circulation patterns. This is particularly true when precipitation is primarily caused by the advection of air masses to the Alps from the North Atlantic or the Mediterranean Sea, as is the case under cold conditions. Alpine precipitation patterns during the Lateglacial period can hence be interpreted in terms of past atmospheric circulation patterns in continental Europe. In this paper, glacier-climate models are used for the reconstruction of Younger Dryas precipitation patterns based on changes in equilibrium line altitudes of Alpine glaciers. This type of research provides important information concerning the range of past precipitation variability against which present climatic changes in the Alps can be assessed. Also, unravelling the spatial patterns of Alpine precipitation allows us to gain a better understanding of forcing mechanisms behind precipitation changes.

The „Alpine Lateglacial“" (ca. 19,000 - 11,500 cal BP) was characterised by a rapid downwasting of the large piedmont and valley glacier systems, which was interrupted by several successively smaller readvances associated with short cold and/or more humid phases („Stadials"). The morainic systems associated with these advances form the basis for the definition of a glacial event sequence (Maisch 1982). 
The Younger Dryas (YD) cold phase (Greenland Stadial 1, 12,650 - 11,500 cal. BP; Björck et al. 1998) in the Alps is represented by the „Egesen Stadial“. In many valleys, three distinct sets of YD moraines can be found (Egesen-I to Egesen-III), jointly representing the last major cold event prior to the Holocene. Widespread rock glacier development after the Egesen-I phase documents the existence of permafrost down to altitudes of $2000 \mathrm{~m}$ asl and below (Sailer and Kerschner 2000). Surface exposure ages of an Egesen-I moraine at Julier pass (Switzerland) show that the moraine stabilised a few centuries after the onset of the Younger Dryas (Ivy-Ochs et al. 1996).

Lateglacial glaciers play an important role as a palaeoclimatic data source, because glacier behaviour is directly controlled by climate on a time-scale on the order of several decades to a few centuries. The spatial coverage of glacier data for selected time-slices, such as the early Younger Dryas, is very dense in the Alps. The data set for this study comprises 160 data points.

\section{Theoretical framework}

The accumulation area of a glacier is separated from the ablation area by the equilibrium line (EL), where accumulation exactly equals ablation. The equilibrium line altitude (ELA) of former glaciers can be determined from glacier maps, if past glacier extents are sufficiently well documented. Under alpine conditions, the accumulation area is usually twice as large as the ablation area, if the glacier is in equilibrium (Gross et al. 1977). The ELA and the vertical shift of the ELA ( $\triangle E L A)$ are used as principal input parameters for the reconstruction of paleoclimate with glacier-climate models.

\subsection{The glacial-meteorological approach}

A vertical shift of the ELA is entirely caused by climatic factors, be it a change in accumulation (c) or in ablation (a), or both. If one parameter ( $c$ or a) can be estimated reasonably well, the other can be, at least in principle, calculated from $\triangle \mathrm{ELA}$. The perturbation analysis of the mass and energy balance equation by Kuhn $(1981,1989)$ allows us to analyse the physical mechanisms controlling ELA fluctuations. This approach is referred to as the ,glacial-meteorological model“" (GMM) below.

A change in accumulation $(\Delta c)$ and/or ablation $(\Delta a)$ causes a shift of the ELA along the vertical gradients of accumulation $(\partial \mathrm{c} / \partial \mathrm{z})$ and ablation $(\partial \mathrm{a} / \partial \mathrm{z})$ until balanced conditions are achieved again (1).

$$
\Delta \mathrm{c}+\frac{\partial \mathrm{c}}{\partial \mathrm{z}} \Delta \mathrm{ELA}=\Delta \mathrm{a}+\frac{\partial \mathrm{a}}{\partial \mathrm{z}} \Delta \mathrm{ELA}
$$

Expressing ablation as the consequence of the energy supplied to the glacier surface, equation (1) can be written as

$$
\Delta \mathrm{c}+\frac{\partial \mathrm{c}}{\partial \mathrm{z}} \Delta \mathrm{ELA}=\frac{\tau}{\mathrm{Lm}}\left[-\mathrm{G} \partial \mathrm{r}+\partial \mathrm{A}+\frac{\partial \mathrm{A}}{\partial \mathrm{z}} \Delta \mathrm{ELA}+\alpha\left(\partial \mathrm{Ts}+\frac{\partial \mathrm{Ts}}{\partial \mathrm{z}} \Delta \mathrm{ELA}\right)\right]-\tau \partial \mathrm{S}\left(1-\frac{\mathrm{Ls}}{\mathrm{Lm}}\right)
$$


with $\tau$ as the duration of the ablation period, $L \mathrm{~m}$ and $\mathrm{Ls}$ as the latent heat of fusion and of sublimation, respectively, $G$ as the global radiation, $r$ as the albedo, $A$ as the atmospheric long wave radiation, $\alpha$ as the turbulent heat exchange coefficient, Ts as the air temperature of the ablation period and $\mathrm{S}$ as the sublimation. All changes of variables which are not incorporated in equation (2) are considered to be zero. As a first approximation it is assumed that all vertical lapse rates are linear. Finally, the change in precipitation can be calculated as $\Delta \mathrm{p}=\Delta \mathrm{c} / 1.5$ under the assumption that accumulation on a glacier surface is $50 \%$ larger than precipitation due to wind drift and avalanching (for details see Kuhn 1981, 1989; Kaser and Osmaston 2002).

\subsection{Statistical models}

Statistical models relate climatic parameters governing ablation with parameters governing accumulation using regression techniques. This approach was used for the first time by Ahlmann (1924) for glacierized basins in Norway. It shows that precipitation at the ELA increases exponentially with increasing summer temperatures. Since then, various authors derived equations with summer temperature as a parameter for ablation and with precipitation-related data as a parameter for accumulation. This works surprisingly well, since summer temperature seems to be a good parameter for all processes causing ablation (Ohmura 2001).

Statistical models should use physically meaningful variables, but they are not physical models. Therefore, they may only be used within the boundary conditions of the dataset from which they were derived and require a careful climatological calibration and adaptation of the input data. Input data, which are not compatible with the model parameters, may cause considerable errors. Table 1 lists various statistical models and the parameters used for their calculation.

In order to calculate precipitation changes for a time interval in the past (e.g. early Younger Dryas), a reliable estimate of present-day precipitation in the currently glacierized areas is necessary. Measuring precipitation in glacierized high mountain regions is, however, extremely difficult and the spatial resolution of gridded precipitation data (Frei and Schär 1998) is too coarse to be used as a reference. Therefore, it is appropriate to determine present-day precipitation indirectly from present-day ELAs using a glacier-climate model. Under Alpine conditions, the normal period 1931-60 seems to be most useful as a reference period because it is well documented and provides the climatic background for the glacier inventories in the European Alps. Modern precipitation at the ELA can then be determined with the glacier-climate models by Ohmura et al. (1992), Krenke (1975) or Khodakov (1975). Wherever these models have been tested against measured Alpine data, the results fit quite well. Results obtained from the Norwegian model and the relation by Shi et al. (1992) are systematically too high in warmer areas of the Alps.

For the reconstruction of past precipitation, all models require external information on temperature change from non-glacial proxy data. Glacial and non-glacial data sources have to be synchronised, and temperature proxy data have to be available on a time scale, which is roughly equivalent to the response time of glaciers (i.e. several decades to a few centuries). 
Table 1: Statistical glacier-climate models (temperatures are in ${ }^{\circ} \mathrm{C}$, accumulation / precipitation in $\left.\mathrm{kg} \mathrm{m}^{-2} \mathrm{a}^{-1}\right)$.

$c=75 \mathrm{e}^{(0.9 \mathrm{Ts}-0.45)}+1173 \quad$ (Ahlmann 1924)

c: Runoff from glacierized basins in Norway, Ts: standard mean summer temperature June-September, vertical temperature lapse rate $-0.7 \mathrm{~K} / 100 \mathrm{~m}$.

$\mathrm{c}=\mathrm{a}=0.96(\mathrm{Ts}+10)^{2.93}$

(Khodakov 1975)

a: annual ablation, Ts: standard mean summer temperature (June-August), data from glacierized areas in the Soviet Union.

$\mathrm{c}=\mathrm{a}=(\mathrm{Ts}+9.5)^{3}$

(Krenke 1975)

Same glacier data as Khodakov, Ts: mean temperatures from long temperature series (1881 - 1960) in the Soviet Union, extrapolated to the ELA and reduced by $1 \mathrm{~K}$ to account for temperatures near the glacier surface.

$P(E L A)=645+296 \mathrm{Ts}+9 \mathrm{Ts}^{2}$

(Ohmura et al. 1992)

P(ELA): Precipitation at the ELA (winter mass balance + summer precipitation), Ts: mean summer temperature (June-August) of the free atmosphere at the ELA, world-wide data set.

$P w=915 e^{(0.339 T)}$

(Norwegian Model; "Liestølequation", e.g. Dahl and Nesje 1996)

Pw: winter precipitation at the ELA, T: summer temperature at the ELA (May-September), temperature lapse rate $-0.65 \mathrm{~K} / 100 \mathrm{~m}$, data from Norwegian glaciers by $O$. Liestol.

$\mathrm{P}(\mathrm{ELA})=441 \mathrm{e}^{(0.4225 \mathrm{~T})}$

(Shi et al. 1992)

P(ELA): annual precipitation at the ELA, T: summer temperature (not specified), data from glacierized areas in West China (mainly Tibet).

\section{Application: Alpine precipitation patterns during the Younger Dryas}

The early Younger Dryas in the Alps provides a good testing ground for the determination of palaeoprecipitation with either statistical glacier-climate models or the GMM. Glacier advances are well documented in the field (maximum advance of the "Egesen Stadial") and glacier topographies can be reliably plotted on topographic maps. The modeling approach is outlined in Figure 1; more details can be found in Kerschner et al. (2000).

The crucial first step in palaeoprecipitation reconstructions is the determination of summer temperature depression ( $\Delta \mathrm{Ts}$ ) at decadal to century-scale resolution. In the Alps, estimates for Younger Dryas $\Delta \mathrm{Ts}$ vary between about -1.5 and $-7.5 \mathrm{~K}$ (Lotter et al. 2000), depending on the proxy record used. 
Field data: moraines, absolute ages

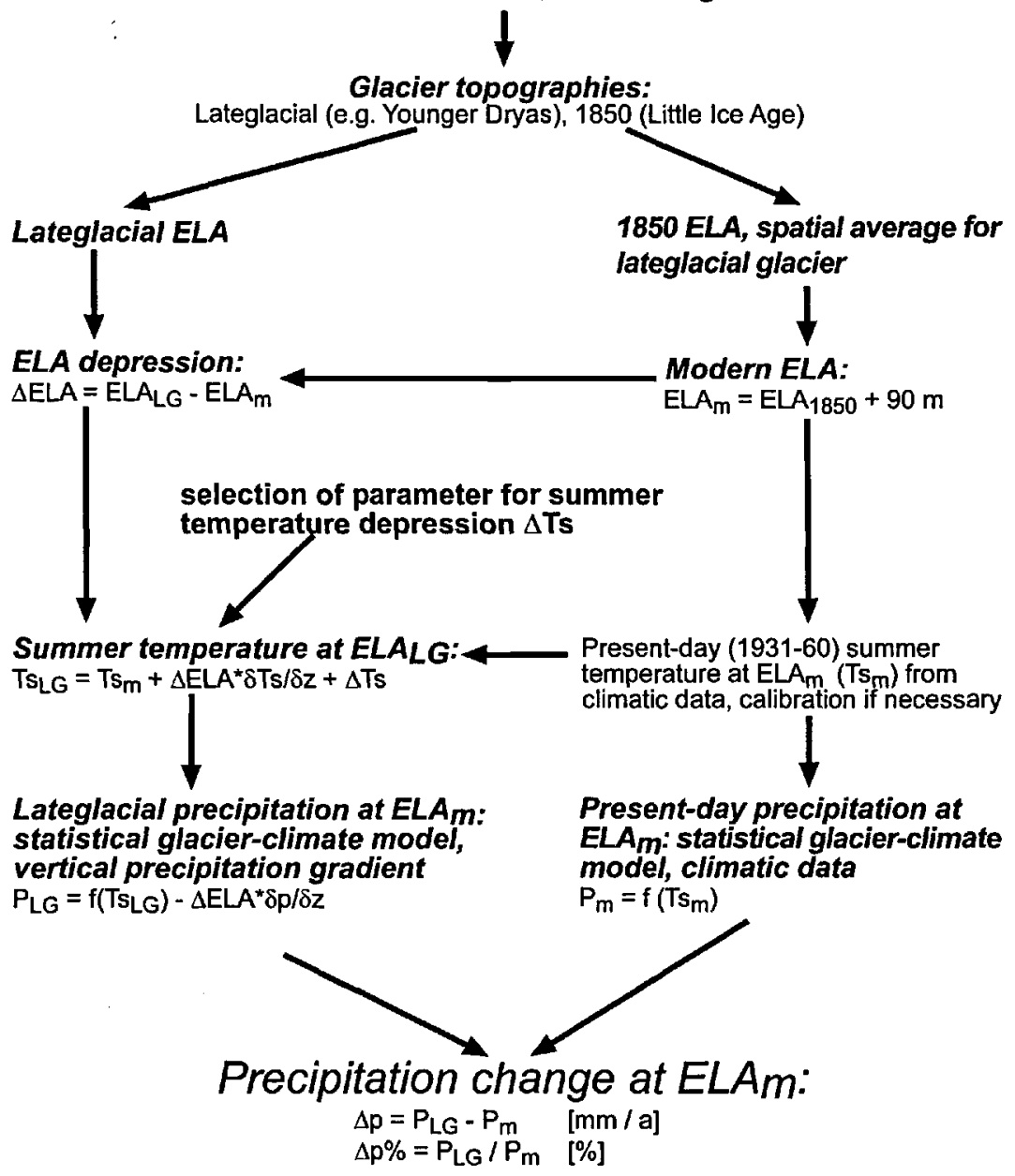

Figure 1: Flow chart for the determination of precipitation change with glacier-climate models.

As upper timberline is largely dependent on summer temperature, timberline fluctuations can be used to calculate $\Delta T$ Ts. However, timberline reconstructions for the YD vary substantially across the Alps. If an average timberline depression on the order of $-500 \mathrm{~m}$ is assumed (Bortenschlager 1984; Burga and Perret 1998), $\Delta \mathrm{Ts}$ during the early Younger Dryas was about $-3.5 \mathrm{~K}$, which is comparable to results from Schwalb et al. (1994). Recent studies suggest a timberline depression on the order of $-800 \mathrm{~m}$ to $-1000 \mathrm{~m}$, corresponding to a $\Delta \mathrm{Ts}$ of -5.6 to $-7 \mathrm{~K}$ (Tobolski and Ammann 2000; Wick 2000). Future research will have to resolve whether these differences are associated with methodological differences in timberline reconstructions or regional differences in the YD temperature decline across the Alps.

ELA depressions of Egesen-maximum glaciers close to the northern fringe of 
the Austrian Alps are on the order of $-500 \mathrm{~m}$, whereas in the central Alps they are on the order of $-200 \mathrm{~m}$ relative to the ELA of 1850 . Assuming a spatially constant temperature depression and glaciers in equilibrium, the observed spatial variability of ELA depression can be interpreted in terms of spatial differences in precipitation change. With a $\Delta$ Ts of $-3.5 \mathrm{~K}$, precipitation during the early Younger Dryas should have been somewhat higher than today along the northern fringe of the Alps $(+15 \%)$ and considerably lower than today in the well-sheltered valleys of the interior (up to $-30 \%$; Fig. 2). With an assumed $\Delta \mathrm{Ts}$ of $-4.5 \mathrm{~K}$, the respective values are $\pm 0 \%$ along the northern fringe of the Alps and -50 to $-60 \%$ in the interior. In any case, such a pattern is typical for a more zonal westerly circulation under cold conditions, as simulated for the YD interval by Atmospheric General Circulation Models (Renssen et al. 2001; Renssen and Isarin 1998).

The Norwegian model indicates that winter precipitation was more reduced than annual precipitation. This is reasonable, as winter precipitation under cold conditions is generally very low. Assuming a NW - SE gradient of temperature change during the $\mathrm{YD}$, with a stronger temperature depression in the NW part of the Alps (Isarin and Bohncke 1998), the contrast in precipitation change between the northern fringe of the Alps and the more continental interior would have been less pronounced.

A summer temperature depression of $-7.5 \mathrm{~K}$ (Lotter et al. 2000) requires full arid conditions in the central Alps. Depending on the model used, precipitation would have been reduced by 40 to $60 \%$ along the northern fringe of the Alps and by 75 to almost $100 \%$ in the valleys of the interior. In more than $75 \%$ of the cases, summer temperatures at the ELA would have been negative, which is typical for glaciers in a cold and arid environment. As other glaciological parameters like basal shear stresses of early YD glaciers were rather similar to those of modern, well nourished glaciers (Maisch and Haeberli 1982) in more humid climates, the assumption of a spatially constant severe summer temperature depression requires further study.

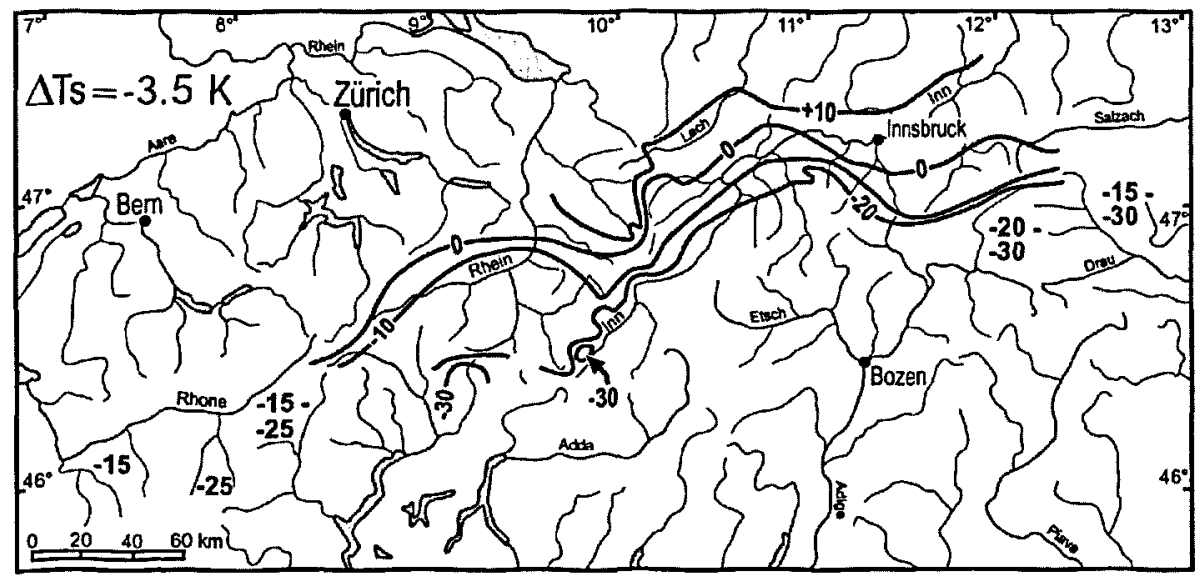

Figure 2: Early Younger Dryas precipitation change in the Alps under the assumption of $\Delta \mathrm{Ts}=-\mathbf{3} .5 \mathrm{~K}$; data from 160 Egesen-I glaciers. 


\section{Some perspectives for future research}

The reconstruction of precipitation change based on past ELA fluctuations can give at least "semi-quantitative" information about an important factor of the hydrological cycle during the Lateglacial. The spatial patterns of precipitation change can serve as a test for the reliability of Atmospheric General Circulation Models. For future research, a few points should be mentioned, which may serve as guidelines.

- The simulation of mass balance gradients with the glacial-meteorological model, which has shown promising results for modelling tropical glaciers (Kaser and Osmaston 2002), should also be applicable to glaciers of the Alpine Lateglacial. It could be used to test the influence of parameters such as a) shorter ablation periods than today, b) the effects of more pronounced seasonal contrasts in temperature and precipitation, c) a possible increase in sublimation from the glacier surface and d) albedo changes.

- The glacier bed topography of many Lateglacial glaciers is well known, which allows a three-dimensional reconstruction of the glacier topography. This is an important prerequisite for the application of more sophisticated glaciological models, which are largely independent of climatic information from non-glacial proxy-data. Ultimately, these approaches combine climate models, mass and energy balance models and glacier flow models (e.g. Kull and Grosjean 2000). A simplified approach was used by Kerschner et al. (1999) to reconstruct the climatic conditions during the Gschnitz Stadial (ca. 16,000 cal B.P.).

- There is still a substantial need for reliable data on summer temperature change in the Alps during the Lateglacial on a timescale of about 100 to 300 years. A greater spatial coverage of quantitative temperature reconstructions would also help to address whether or not Lateglacial temperature changes were uniform across the Alps. If reliable data on temperature change are available, the resulting maps of precipitation change are probably of similar quality as present-day climatological maps of the Alps.

- Lateglacial glacier data, such as past ELAs, are presently available for wide areas of the Alps in Western Austria and Switzerland. In these areas, we have a fairly good overview of the distribution of Younger Dryas glaciers and also a reasonably good idea about Pre-Bølling Stadials (older than 14,700 cal BP). There are, however, still significant gaps in our knowledge both in space and time. Data from the Northern Alps and from areas south of the Alpine Main Ridge are still scarce or more or less completely missing. These regions should be the focus of future studies.

- There is also an urgent need for more reliable absolute ages of the deposits left behind by glacier advances. Modern dating methods (e.g. surface exposure dating with cosmogenic radionuclides, analysis of proglacial lake sediments and U/Th dating of carbonate sinters) should provide sufficient data to at least bracket several periods of glacier advances. This should permit a more reliable correlation between the glacial record from the Alps, proxy data from the circum-alpine region and the large-scale climatic development, as recorded in ice-cores and ocean sediment cores. There still remains much work to be done. 


\section{Acknowledgements}

This study was supported by the Austrian Science Foundation (FWF) under grants $\mathrm{P}-12600 \mathrm{GEO}$ and $\mathrm{P}-15108$.

\section{References}

Ahlmann, H.W:son (1924). Le niveau de glaciation comme fonction de l'accumulation d'humidité sous forme solide. Geografiska Annaler 6, 221-272.

Björck, S., Walker, M. C., Cwynar, L. C., Johnsen, S., Knudsen, K.-L., Lowe, J. J., Wohlfahrt, B., and INTIMATE members (1998). An event stratigraphy for the Last Termination in the North Atlantic region based on the Greenland ice-core record: A proposal by the INTIMATE group. Journal of Quaternary Science 13, 283-292.

Bortenschlager, S. (1984). Beiträge zur Vegetationsgeschichte Tirols I. Inneres Ötztal und unteres Inntal. Berichte des Naturwissenschaftlich-Medizinischen Vereins in Innsbruck 71, 19-56.

Burga, C., and Perret, R. (1998). "Vegetation und Klima der Schweiz seit dem jüngeren Eiszeitalter." Ott, Thun.

Dahl, S. O., and Nesje, A. (1996). A new approach to calculating Holocene winter precipitation by combining glacier equilibrium-line altitudes and pine-tree limits: A case study from Hardangerjøkulen, central southern Norway. The Holocene 6, 381-398.

Frei, Ch., and Schär, Ch. (1998). A precipitation climatology of the Alps from high-resolution rain-gauge observations. International Journal of Climatology 18, 873-900.

Gross, G., Kerschner, H., and Patzelt, G. (1977). Methodische Untersuchungen über die Schneegrenze in alpinen Gletschergebieten. Zeitschrift fïr Gletscherkunde und Glazialgeologie 12, 223-251.

Isarin, R. F. B., and Bohncke, S. J. P. (1998). Mean July temperatures during the Younger Dryas in northwestern and central Europe inferred from climate indicator plant species. Quaternary Research 51, 158-173.

Ivy-Ochs, S., Schlüchter, Ch., Kubik, P., Synal, H.-A., Beer, J., and Kerschner, H. (1996). The exposure age of an Egesen moraine at Julier Pass, Switzerland, measured with the cosmogenic radionuclides ${ }^{10} \mathrm{Be}$, ${ }^{26} \mathrm{Al}$ and ${ }^{36} \mathrm{Cl}$. Eclogae Geologicae Helvetiae 89, 1049-1063.

Kaser, G., and Osmaston, H. (2002). "Tropical Glaciers." Cambridge University Press, Cambridge.

Kerschner, H., Ivy-Ochs, S., and Schlüchter, Ch. (1999). Paleoclimatic interpretation of the early lateglacial glacier in the Gschnitz valley, Central Alps, Austria. Annals of Glaciology 28, 135-140.

Kerschner, H., Kaser, G., and Sailer, R. (2000). Alpine Younger Dryas glaciers as paleo-precipitation gauges. Annals of Glaciology 31, 80-84.

Khodakov, V. G. (1975). Glaciers as water resource indicators of the glacial areas of the USSR. International Association of Hydrological Sciences Publication 104, 22-29.

Krenke, A. N. (1975). Climatic conditions of present-day glaciation in Soviet Central Asia. International Association of Hydrological Sciences Publication 104, 30-41.

Kuhn, M. (1981). Climate and glaciers. International Association of Hydrological Sciences Publication $131,3-20$.

Kuhn, M. (1989). The response of the equilibrium line altitude to climatic fluctuations: Theory and observations. In "Glacier fluctuations and climatic change," (J. Oerlemans, Ed.), pp. 407-417. Kluwer, Dordrecht.

Kull, C., and Grosjean, M. (2000). Late Pleistocene climate conditions in the north Chilean Andes drawn from a climate-glacier model. Journal of Glaciology 46, 622-632.

Lotter, A. F., Birks, H. J. B., Eicher, U., Hofmann, W., Schwander, J., and Wick, L. (2000). Younger Dryas and Alleröd summer temperatures at Gerzensee (Switzerland) inferred from fossil pollen and cladoceran assemblages. Palaeogeography, Palaeoclimatology, Palaeoecology 159, 349-361.

Maisch, M. (1982). Zur Gletscher- und Klimageschichte des alpinen Spätglazials. Geographica Helvetica 37, 93-104.

Maisch, M., and Haeberli, W. (1982). Interpretation geometrischer Parameter von Spätglazialgletschern im Gebiet Mittelbünden, Schweizer Alpen. In „Beiträge zur Quartärforschung in der Schweiz," (Physische Geographie 1, M. Gamper, Ed.), pp. 111-126. Geographisches Institut der Universität, Zürich. 
Ohmura, A. (2001). Physical basis for the temperature-based melt-index method. Journal of Applied Meteorology 40, 753-761.

Ohmura, A., Kasser, P., and Funk, M. (1992). Climate at the equilibrium line of glaciers. Journal of Glaciology 38, 397-411.

Renssen, H., and Isarin, R. F. B. (1998). Surface temperature in NW Europe during the Younger Dryas: AGCM simulation compared with temperature reconstructions. Climate Dynamics 14, 33-44.

Renssen, H., Isarin, R. F. B., Jacob, D., Podzun, R., and Vandenberghe, J. (2001). Simulation of the Younger Dryas climate in Europe using a regional climate model nested in an AGCM: Preliminary results. Global and Planetary Change 30, 41-57.

Sailer, R., and Kerschner, H. (2000). Equilibrium line altitudes and rock glaciers in the Ferwall-Group (Western Tyrol, Austria) during the Younger Dryas cooling event. Annals of Glaciology 28, 141-145.

Schwalb, A., Lister, G. S., and Kelts, K. (1994). Ostracode carbonate $\mathrm{d}^{18} \mathrm{O}$ - and $\mathrm{d}^{13} \mathrm{C}$-signatures of hydrological and climatic changes affecting Lake Neuchâtel, Switzerland, since the late Pleistocene. Journal of Paleolimnology 11, 3-17.

Shi, Y., Zheng, B., and Li, S. (1992). Last glaciation and maximum glaciation in the Qinghai-Xizang (Tibet) Plateau: A controversy to M. Kuhle's ice sheet hypothesis. Zeitschrift für Geomorphologie N.F., Supplementband 84, 19-35.

Tobolski, K., and Ammann, B. (2000). Macrofossils as records of plant responses to rapid Late Glacial climatic changes at three sites in the Swiss Alps. Palaeogeography, Palaeoclimatology, Palaeoecology 159, 251-259.

Wick, L. 2000. Vegetational response to climatic changes recorded in Swiss Late Glacial lake sediments. Palaeogeography, Palaeoclimatology, Palaeoecology 159, 231-250. 